\title{
A novel cathepsin $\mathrm{D}$ mutation in 2 siblings with late infantile neuronal ceroid lipofuscinosis
}

\author{
Jineesh Thottath, MD,* Shamsudheen Karuthedath Vellarikkal, PhD, * Rijith Jayarajan, MSc, * \\ Ankit Verma, MSc, Manu Manamel, MD, Archana Singh, PhD, V. Raman Rajendran, MD, \\ Sridhar Sivasubbu, PhD, and Vinod Scaria, PhD
}

Neurol Genet 2019;5:e302. doi:10.1212/NXG.0000000000000302

\author{
Correspondence \\ Dr. Sivasubbu \\ s.sivasubbu@igib.res.in \\ or Dr. Scaria \\ vinods@igib.in
}

Neuronal ceroid-lipofuscinosis (NCL) is a heterogeneous and rare lysosomal storage disorder characterized by the accumulation of autofluorescent materials—ceroid and lipofuscin - in the cytoplasm. ${ }^{1}$ It is manifested as a progressive destruction of neuronal cells resulting in brain atrophy, loss of vision, and other neurodegenerative phenotypes. ${ }^{1}$ Over 446 mutations in different genes have been cataloged in the NCL mutation database (ucl.ac.uk/ncl/mutation). The overlapping phenotypes and involvement of multiple genes indicate the difficulty in the accurate diagnosis of NCLs. ${ }^{2}$ The genetic characterization using whole exome sequencing approach can accurately diagnose NCLs. ${ }^{3,4}$ We report a phenotypically inconclusive case of a rare occurrence of NCL in siblings and identified a mutation in CTSD using whole exome sequencing.

\section{Case report}

This study has been approved by institutional ethical committee (IHECC proposal No. 8), and written informed consent was obtained from all participants. Two of 3 siblings, born to a thirddegree consanguineous marriage (figure, A) were apparently normal at birth and during the immediate perinatal period. They attained normal developmental milestones until the age of 3 years. A regression in the milestone was noted after 3 years of age, which progressed to complete blindness in 3-4 years. The motor system involvement started as incoordination of the upper limb, later progressed with age to dysarthria, prosopagnosia, ataxia with tremor, and weakness of limbs. By the age of 7 , both the siblings were incapacitated and bedridden. There was no history of seizures. The third sibling, the eldest among the 3 , was apparently normal and had attained regular milestones of development.

Preliminary examination revealed spastic rigidity of all 4 limbs and bilateral extensor plantar responses. Ophthalmic examination showed pigmentary degeneration of retina with optic atrophy with a suggestive provisional diagnosis of retinitis pigmentosa. An MRI of the brain showed diffuse cerebral and cerebellar atrophy with optic nerve atrophy and white matter abnormalities. Gradient recalled echo-T2 weighted MRI images revealed symmetric hypointense signals in the region of substantia nigra. In addition, a large midline cyst was noted in the inferior part of posterior fossa communicating with the cisterna magna posteroinferiorly and the fourth ventricle anteriorly (figure, B). Both siblings had similar radiologic findings (figure, B). Echocardiogram showed concentric left ventricular hypertrophy, speckled appearance of myocardium, mild mitral regurgitation dynamic left ventricle outflow tract obstruction, high systolic anterior motion, and mild mitral regurgitation. The clinical and radiologic features

\footnotetext{
*Contributed equally and would like to be known as joint first authors.
}

From the Department of Radiodiagnosis (J.T., M.M., V.R.R.), Government Medical College, Kozhikode, Medical College PO, Kozhikode, Kerala 673008, India; Genomics and Molecular Medicine Unit (S.K.V., R.J., A.V., A.S., S.S.), CSIR Institute of Genomics and Integrative Biology; Academy of Scientific and Innovative Research (AcSIR) (S.K.V., S.S., V.S.), CSIR-IGIB South Campus; and GN Ramachandran Knowledge Center for Genome Informatics (V.S.), CSIR Institute of Genomics and Integrative Biology, Delhi, India.

Funding information and disclosures are provided at the end of the article. Full disclosure form information provided by the authors is available with the full text of this article at Neurology.org/NG.

The Article Processing charge was funded by the authors.

This is an open access article distributed under the terms of the Creative Commons Attribution-NonCommercial-NoDerivatives License 4.0 (CC BY-NC-ND), which permits downloading and sharing the work provided it is properly cited. The work cannot be changed in any way or used commercially without permission from the journal. 
A

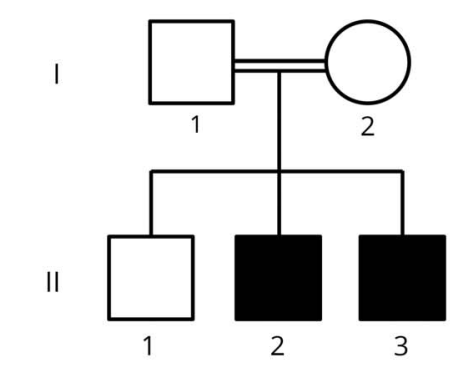

C

Code: ATGC

I-1

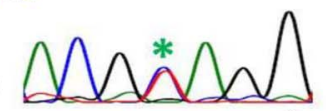

$1-2$
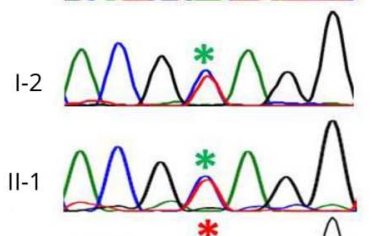

II-2

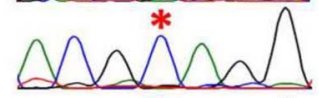

II-3

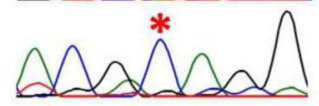

B

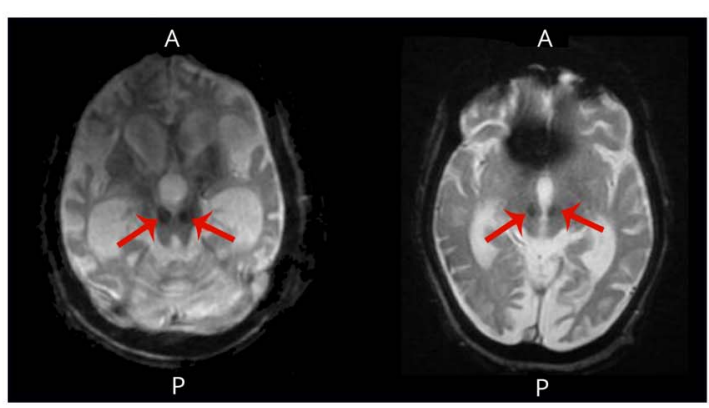

D

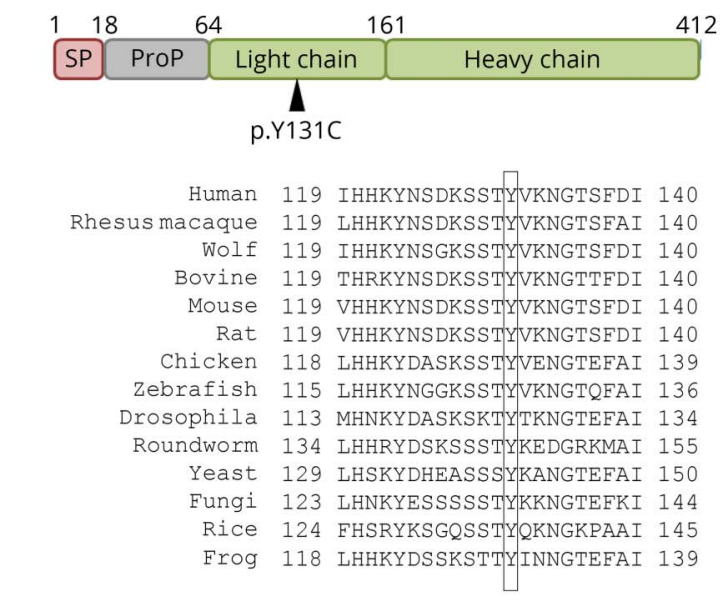

F

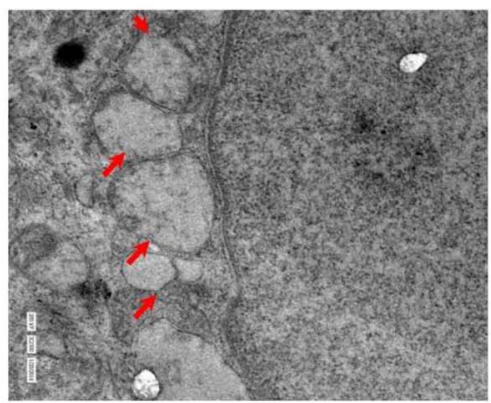

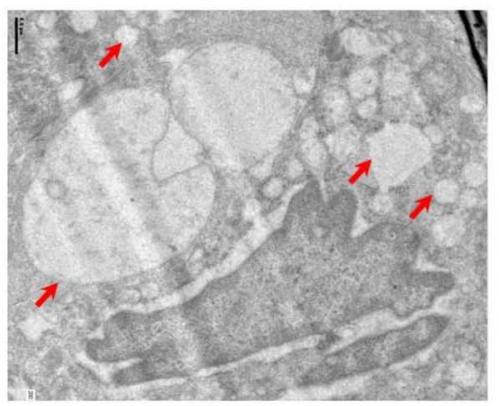

(A) Pedigree of the family. Affected individuals are shaded in black. (B) T2 gradient recalled echo images showing a large midline cyst (highlighted with arrows) in the inferior part of posterior fossa communicating with the cisterna magna posteroinferiorly and the fourth ventricle anteriorly for both the children, respectively. (C) Chromatogram depicting the capillary sequencing result of CTSD c.A392G in the family, and the mutation position is highlighted with asterisks (red for affected individuals). (D) The domain structure of CTSD protein marked with the identified mutation (p.Y131C). (E) Conservation of CTSD Y131 across other species. (F) TEM image of the skin biopsy showing vacuolating bodies of varying sizes largely localized around the nucleus. The vacuolating bodies are highlighted with red arrows. suggested a provisional diagnosis of "neurodegeneration with brain iron accumulation syndrome" with the unusual clinical manifestation, possibly an autosomal recessive inheritance.

Whole exome sequencing analysis identified a homozygous mutation c.A392G (p.Y131C) in CTSD to be the putative candidate, which was found to be cosegregated in parents in the heterozygous state using Sanger sequencing (figure, C).

\section{Discussion}

In the present study, we demonstrate the utility of whole exome sequencing in the accurate diagnosis of a rare and unusual neurodegenerative disorder in 2 siblings of a family from southern India. The mutation c.A392G introduces an amino acid change of p.Y131C in CTSD. The Y131 lies in the light chain of CTSD (figure, D). The CTSD chain (residues 64-412) contains crucial sites that are required for the catalytic activity of the enzyme. ${ }^{5}$ Furthermore, the Y131 residue in CTSD was found to be conserved across species (figure, E), suggesting the importance of this residue in CTSD activity. Homozygous pathogenic variations in CTSD were previously reported to cause the rare neuronal ceroid lipofuscinosis type $10 .^{6}$ The present variation was reported in the ExAC database as a single heterozygous case with an allele frequency of 0.0000083 , whereas it was absent in the 1000 Genome, NHLBI Exome Sequencing Project, or internal exome database of unrelated individuals from India, suggesting the rarity of this variation. Although the majority 
of the clinical features corroborated with a provisional diagnosis of NCL, the absence of typical MRI findings and epileptic seizures demanded further clinical evaluation. Because lipofuscin deposits can be observed elsewhere in the body in patients with NCLs, we attempted to evaluate skin biopsies by transmission electron microscopy (TEM). TEM analysis revealed that the skin layers were structurally normal; however, vacuolated bodies of varying sizes similar to typical lipofuscin deposits were observed in all the skin layers especially localized around the nucleus (figure, F). Together, the genotype-phenotype correlation confirms the diagnosis of NCL type 10. Thus, genetic testing using whole exome sequencing has enabled the accurate and timely diagnosis in rare neurologic conditions such as NCL10.

\section{Author contributions}

Clinical and radiologic workup of the patient and collection of samples for genetic testing: J. Thottath, M. Manamel, and V.R. Rajendran. DNA isolation, preparation of exome enrichment and sequencing, analysis, and validation and interpretation: S.K. Vellarikkal, A. Verma, and R. Jayarajan. TEM experiments: A. Singh. Study concept and design and overseeing all the experiment and validation: S. Sivasubbu and V. Scaria. Writing of the manuscript: S.K. Vellarikkal, R. Jayarajan, J. Thottath, V.R. Rajendran, V. Scaria, and S. Sivasubbu.

\section{Acknowledgment}

The authors acknowledge Ms. Rowmika Ravi for helping with manuscript preparation and the GUaRDIAN consortium for the scientific support. The authors also acknowledge Dr. Najeeba Riyaz for the skin biopsy and Dr. Riyaz Arakkal and Dr. Rajeevan for the clinical workup of the family.

\section{Study funding}

The authors acknowledge funding from the Council of Scientific and Industrial Research (CSIR), India, through Grant No. BSC0212. The funders did not have any role in study design; data collection, analysis, and interpretation; writing the report; and the decision to submit the report for publication.

\section{Disclosure}

J. Thottath, S.K. Vellarikkal, R. Jayarajan, A. Verma, M. Manamel, A. Singh, and V.R. Rajendran report no disclosures. S. Sivasubbu has received research support from the Council of Scientific and Industrial Research (CSIR), India. V. Scaria has served on the editorial boards of Journal of Translational Medicine, PLoS One, Frontiers in Systems Biology, Journal of Orthopaedics, International Journal of Rheumatic Diseases, and PeerJ and has received research support from the Council of Scientific and Industrial Research (CSIR), India. Disclosures available: Neurology.org/NG.

\section{Publication history}

Received by Neurology: Genetics July 6, 2017. Accepted in final form April 5, 2018.

\section{References}

1. Haltia M. The neuronal ceroid-lipofuscinoses: from past to present. Biochim Biophys Acta 2006; 1762:850-856.

2. Wisniewski KE, Zhong N, Kida E, et al. Atypical late infantile and juvenile forms of neuronal ceroid lipofuscinosis and their diagnostic difficulties. Folia Neuropathol 1997;35:73-79.

3. Benitez BA, Alvarado D, Cai Y, et al. Exome-sequencing confirms DNAJC5 mutations as cause of adult neuronal ceroid-lipofuscinosis. PLoS One 2011;6:e26741.

4. Patiño LC, Battu R, Ortega-Recalde $\mathrm{O}$, et al. Exome sequencing is an efficient tool for variant late-infantile neuronal ceroid lipofuscinosis molecular diagnosis. PLoS One 2014;9:e109576.

5. Fusek M, Vetvicka V. Dual role of cathepsin D: ligand and protease. Biomed Pap Med Fac Univ Palacky Olomouc Czech Repub 2005;149:43-50.

6. Hersheson J, Burke D, Clayton R, et al. Cathepsin D deficiency causes juvenile-onset ataxia and distinctive muscle pathology. Neurology 2014;83:1873-1875. 


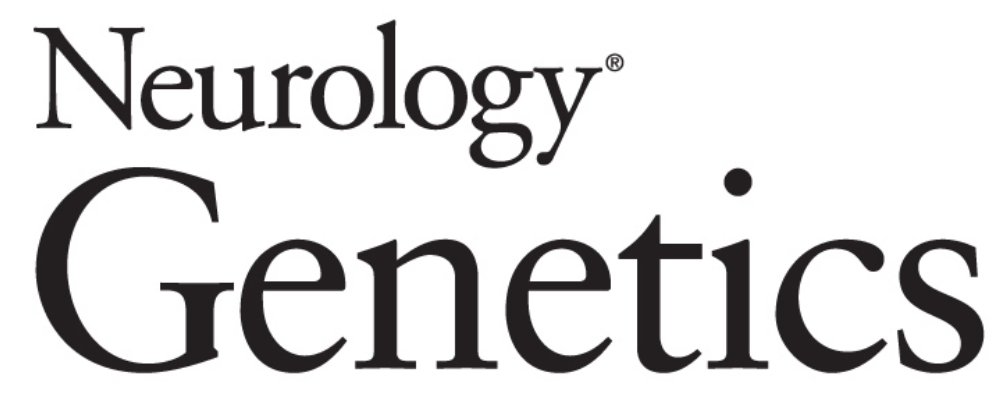

\section{A novel cathepsin D mutation in 2 siblings with late infantile neuronal ceroid lipofuscinosis \\ Jineesh Thottath, Shamsudheen Karuthedath Vellarikkal, Rijith Jayarajan, et al. Neurol Genet 2019;5; \\ DOI 10.1212/NXG.0000000000000302}

This information is current as of April 11, 2019

Neurol Genet is an official journal of the American Academy of Neurology. Published since April 2015, it is an open-access, online-only, continuous publication journal. Copyright Copyright () 2019 The Author(s). Published by Wolters Kluwer Health, Inc. on behalf of the American Academy of Neurology.. All rights reserved. Online ISSN: 2376-7839.

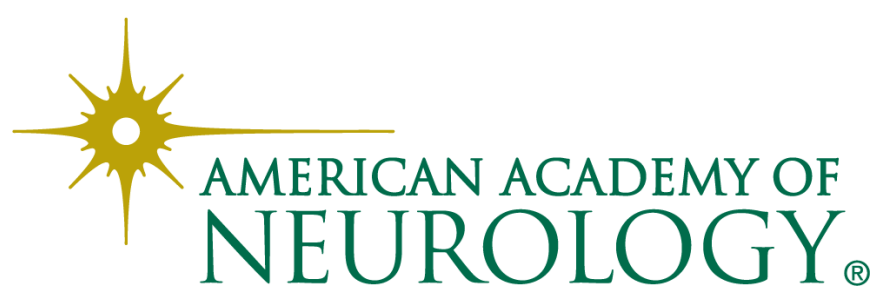




\section{Updated Information \& Services}

\section{References}

Citations

Subspecialty Collections

Permissions \& Licensing

Reprints including high resolution figures, can be found at: http://ng.neurology.org/content/5/3/e302.full.html

This article cites 6 articles, 0 of which you can access for free at: http://ng.neurology.org/content/5/3/e302.full.html\#\#ref-list-1

This article has been cited by 1 HighWire-hosted articles: http://ng.neurology.org/content/5/3/e302.full.html\#\#otherarticles

This article, along with others on similar topics, appears in the following collection(s):

\section{Clinical neurology examination}

http://ng.neurology.org//cgi/collection/clinical_neurology_examination

\section{Motor Control}

http://ng.neurology.org//cgi/collection/motor_control

MRI

http://ng.neurology.org//cgi/collection/mri

Visual loss

http://ng.neurology.org//cgi/collection/visual_loss

Information about reproducing this article in parts (figures,tables) or in its entirety can be found online at:

http://ng.neurology.org/misc/about.xhtml\#permissions

Information about ordering reprints can be found online: http://ng.neurology.org/misc/addir.xhtml\#reprintsus

Neurol Genet is an official journal of the American Academy of Neurology. Published since April 2015, it is an open-access, online-only, continuous publication journal. Copyright Copyright $\odot 2019$ The Author(s). Published by Wolters Kluwer Health, Inc. on behalf of the American Academy of Neurology.. All rights reserved. Online ISSN: 2376-7839.

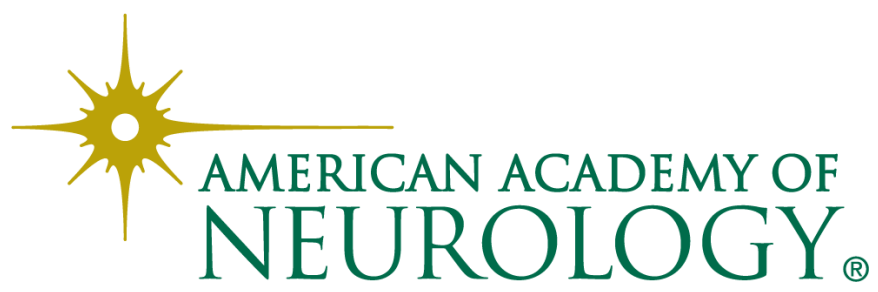

